\title{
A Rare Cause of Hand Infection: Streptococcus Constellatus
}

\section{Una rara causa de infección de la mano: Streptococcus Constellatus}

\author{
Rúben Malcata Nogueira1(i)
${ }^{1}$ Department of Reconstructive and Aesthetic Surgery, Centro Hospitalar Lisboa Ocidental, Lisboa, Portugal
2 Department of Reconstructive and Aesthetic Surgery, Hospital Garcia de Orta, Almada, Portugal
Rev Iberam Cir Mano 2020;48:53-55.

Carolina Vasconcelos ${ }^{2 \odot}$

Nelson Teixeira1뭉

Address for correspondence Rúben Malcata Nogueira, MD, Rua 25 de Abril, 8, 2600-541, Alhandra, Portugal (e-mail: malcatanogueira@gmail.com).

\section{Abstract \\ Keywords \\ - hand infection \\ - streptococcus \\ - streptooccus constellatus \\ - milleri}

\section{Resumen}

\section{Palabras clave}

- infección de la mano

- estreptococo

- streptococcus constellatus

- Milleri
Hand infections represent common medical and surgical challenges that endanger delicate structures with severe consequences if not promptly addressed. Early identification and management are essential to achieve optimal outcomes. To the best of our knowledge this is the first reported case caused by Streptococcus constellatus, in which a severe periungueal infection evolved rapidly with septic thrombosis of digital vessels and culminated in amputation. This microorganism belongs to a group of commensal bacteria, Streptococcus milleri, that causes dental, peritonsillar and sinus abscesses. When bacteriemia outbursts, distant abscesses may form or endocarditis may ensue. A missed diagnosis and treatment can induce important morbidities, often delayed by the difficult isolation of the agent in the laboratory and its complex mechanisms of antibacterial resistance. This article focus on the importance of identifying serious hand infections requiring urgent or emergent treatment, since delayed or inadequate identification and management can lead to important and permanent deficits.

Las infecciones de las manos representan desafíos médicos y quirúrgicos comunes que ponen en peligro estructuras delicadas con graves consecuencias si no se abordan con prontitud. La identificación y el manejo tempranos son esenciales para lograr resultados óptimos. Hasta donde sabemos, este es el primer caso reportado causado por Streptococcus constellatus, en el cual una infección periungueal severa evolucionó rápidamente con trombosis séptica de vasos digitales y culminó en amputación. Este microorganismo pertenece a un grupo de bacterias comensales, Streptococcus milleri, que causa abscesos dentales, periamigdalinos y sinusales. Cuando estalla la bacteriemia, pueden formarse abscesos distantes o puede producirse endocarditis. Un diagnóstico y tratamiento fallados pueden inducir morbilidades importantes, a menudo retrasadas por el difícil aislamiento del agente en el laboratorio y sus complejos mecanismos de resistencia antibacteriana. Este artículo se centra en la importancia de identificar infecciones graves de las manos que requieren tratamiento urgente o de emergencia, ya que la identificación y el manejo retrasados o inadecuados pueden conducir a déficits importantes y permanentes. received

September 8, 2019

accepted

March 10, 2020
DOI https://doi.org/

10.1055/s-0040-1712093. ISSN 1698-8396.
Copyright $\odot 2020$ Thieme Revinter

Publicações Ltda, Rio de Janeiro, Brazil
License terms

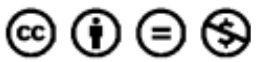




\section{Introduction}

Hand infections represent common medical and surgical challenges that often endanger delicate anatomical structures, with severe consequences if not treated promptly. Alexander Fleming's discovery of Penicillin in 1929 had a revolutionary impact on the way this entity is addressed. The early institution of appropriate antibiotherapy has considerably reduced short- and long-term morbidity, and virtually eliminated mortality. However, medical treatment is often not enough, and timely debridement and surgical drainage must always be considered. ${ }^{1}$

In our Emergency Department, hand infections are increasingly frequent, mainly in the form of eponychia, cellulite, felons or tenosynovitis. The most common mechanism is direct inoculation, either caused by animal or human bites, stings or use of intravenous substances. The occurrence of infection depends not only from individual agent virulence factors, but also from the host susceptibility and immune status. Human immunodeficiency virus infection, uncontrolled or undiagnosed diabetes mellitus, immunosuppressor drugs use and toxic substance abuse are among the most frequent comorbidities found in our patient population. Besides their increased susceptibility, they also present frequently with polymicrobial infections or antibiotic-resistant agents, or even with subtle initial presentations, delaying the diagnosis and management or leading to a poorer result.

The most frequently isolated microorganism in hand infections is Staphylococcus. However, whenever possible, hand infections should have a microbiological analysis, with the identification of the causative organism, as well as its antibiotic susceptibility profile. Some bacteria, like S. constellatus, cause an extremely aggresive clinical course, that can lead to disatrous outcomes if not timely diagnosed and treated. ${ }^{2}$ The ocurrence of these rare infections underline the need to institute culture-based antibiotherapy and to complement it with thorough surgical debridement.

\section{Case Report}

A 55-year-old man with previously undiagnosed type 2 diabetes mellitus and heavy smoking habits presented with a 2 -week history of painful and swollen third digit of his left hand. There was no history of a penetrating injury to that finger, paresthesias or systemic signs such as fever or chills. The patient reported only a mild periungueal infection some days before these symptoms ensued. At presentation, there was necrotic tissue both on distal and middle phalanxes, especially on the dorsal aspect, and serous fluid drained spontaneously from

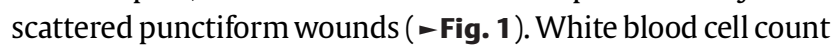
was $20,000 \mathrm{u} / \mathrm{l}$ with neutrophilia, C-Reactive Protein was 14$\mathrm{mg} / \mathrm{dl}$, and glucose level was $275 \mathrm{mg} / \mathrm{dl}$. X-rays excluded the presence of foreign bodies or osteomyelitis.

A large amount of mobile debris communicated with the volar subcutaneous tissues and a comprehensive surgical debridement was performed on the day of admission, and collected material was sent for microbiological analysis. The patient was admitted to the Plastic Surgery Department, and

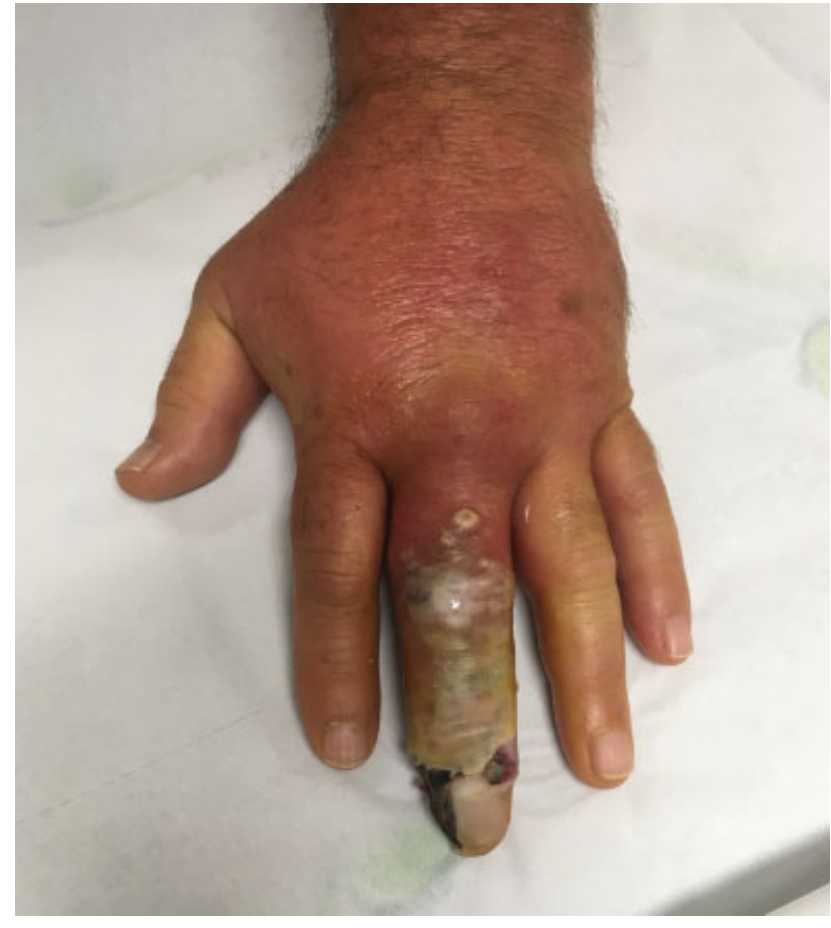

Fig. 1 Hand at presentation.

rigorous glycemic control and empiric broad-spectrum intravenous antibiotic treatment were instituted. Areas of necrosis progressively defined with daily chemical and mechanical debridement (-Fig. 2). On day four of inpatient admission, microbiological results revealed a Streptococcus constellatus infection, and antibiotherapy was switched to Ampicillin and Clindamycin, based on susceptibility test. Despite the undertaken measures, necrosis progressed and affected also the proximal phalanx. One week after presentation, amputation of digital ray was performed and healed uneventfully.

\section{Discussion}

To the authors' best knowledge, this is the first reported case of Streptococcus constellatus hand infection leading to digital amputation. This microorganism belongs to a group of commensal bacteria, Streptococcus milleri (eponym for Willoughby Dayton Miller), which has undergone several changes in its taxonomic classification over the last years. Originally named Streptococcus anginosus (SAG) group, it consists of three species: Streptococcus anginosus, Streptococcus constellatus and Streptococcus intermedius. They are gram-positive organisms of the microaerophilic C- $\beta$ hemolytic group, often found in the oral cavity and in the gastrointestinal and urogenital tracts. Although much less frequent than other subspecies, Streptococcus constellatus can be found in dental biofilms, which can at least in part explain its role in periungueal infection in nail bitters. ${ }^{3-5}$

During the last decade, there has been a growing number of infections caused by these agents, a fact that emphasizes their relevance and high pathogenicity, particularly as cause of abscesses, bacteremia and in patients with cystic fibrosis, especially in those with immunological commitment. ${ }^{1,6,7}$ 


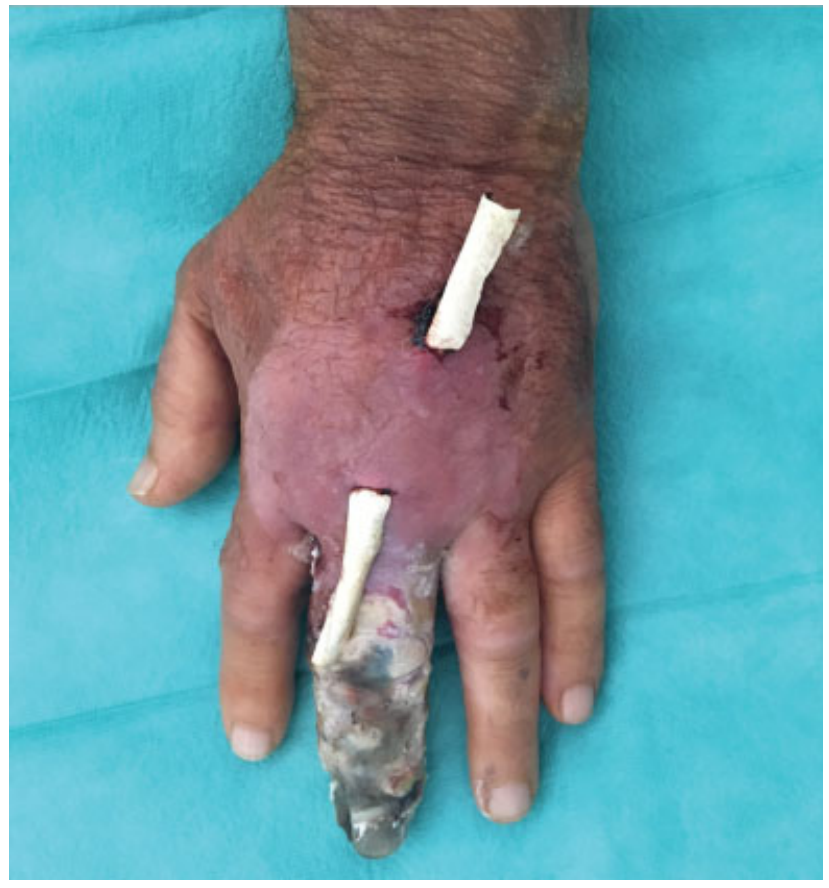

Fig. 2 After first surgical debridment.

A missed diagnosis can induce important morbidities, and it is often delayed by the difficult isolation of the agent in the laboratory, aggravated by the frequent assumption of contamination instead of infection, particularly in polymicrobial infections, that leads to undiagnosed and inappropriately treated cases. Several virulence factors, already described for other related agents, seem to also play a role in the pathogenicity of Streptococcus constellatus. Its adhesion capacity allows the attachment to components of extracellular matrix, such as fibrinogen or fibronectin, and the connection to other bacteria; the capsule production mechanism, which is linked to the formation of abscesses; and the production of $\beta$ hemolysins, all contribute to its high pathogenicity. 1,7,8

To date, hand infections caused by S. constellatus are described infrequently, and we could not find a similar case with such aggressivity and rapid and ramping evolution. The case presented was caused, not only by the pathogenicity and virulence of the microorganism, but also by the host susceptibility, which the authors believe contributed enormously to the adverse outcome. Despite appropriate and aggressive medical and surgical treatment, we could not avoid the digital amputation, which emphasizes the need to adequately and timely diagnose and treat such infections.

\section{Conflict of Interests}

The authors have no conflict of interests to declare.

\section{References}

1 Siegman-Igra Y, Azmon Y, Schwartz D. Milleri group streptococcus-a stepchild in the viridans family. Eur J Clin Microbiol Infect Dis 2012;31(09):2453-2459

2 Rashid RM, Salah W, Parada JP. 'Streptococcus milleri' aortic valve endocarditis and hepatic abscess. J Med Microbiol 2007;56(Pt 2):280-282

3 Tsunashima H, Miyake K, Motono M, Iijima S. Organization of the capsule biosynthesis gene locus of the oral streptococcus Streptococcus anginosus. J Biosci Bioeng 2012;113(03):271-278

4 Jensen A, Hoshino T, Kilian M. Taxonomy of the Anginosus group of the genus Streptococcus and description of Streptococcus anginosus subsp. whileyi subsp. nov. and Streptococcus constellatus subsp. viborgensis subsp. nov. Int J Syst Evol Microbiol 2013; 63(Pt 7):2506-2519

5 Fuentes Olmo J, Ruiz Mariscal M, Uribarrena Amezaga R, Omiste Sanvicente T. [Spontaneous bacterial peritonitis due to Streptococcus constellatus]. Gastroenterol Hepatol 2006;29(09): 595-596

6 Reissmann S, Friedrichs C, Rajkumari R, et al. Contribution of Streptococcus anginosus to infections caused by groups $C$ and $G$ streptococci, southern India. Emerg Infect Dis 2010;16(04): 656-663

7 Claridge JE III, Attorri S, Musher DM, Hebert J, Dunbar S. Streptococcus intermedius, Streptococcus constellatus, and Streptococcus anginosus ("Streptococcus milleri group") are of different clinical importance and are not equally associated with abscess. Clin Infect Dis 2001;32(10):1511-1515

8 Deutschmann MW, Livingstone D, Cho JJ, Vanderkooi OG, Brookes JT. The significance of Streptococcus anginosus group in intracranial complications of pediatric rhinosinusitis. JAMA Otolaryngol Head Neck Surg 2013;139(02):157-160 